\title{
BALANCING RIGHTS AND OBLIGATIONS IN SHARING BENEFITS FROM NATURAL GENETIC RESOURCES: INTERNATIONAL LEGAL RULES
}

\author{
Sergio PEÑA-NEIRA*
}

RESUMEN: Los recursos genéticos naturales es un tema muy relacionado con tópicos como la aplicación, interpretación y el conflicto de leyes. Aquí, el autor explora algunas posibles respuestas a los conflictos de distintas convenciones internacionales, derivadas de derechos y obligaciones relacionados con la biodiversidad, los recursos genéticos naturales y los derechos económicos, sociales y culturales.

ABSTRACT: Natural Genetic Resources is a topic extremely related to issues such application, interpretation and conflict of laws. Here the author explores answers to the problem of conflicts of different international conventions to solve issues of rights and obligations related to the biodiversity, natural genetic reosurces and economic, social and cultural rights.

RÉSUMÉ: Le sujet relatif aux ressources génétiques naturels amène à différents problèmes d'application, d'interprétation et de conflit des lois. Dans cet article, l'auteur fait des propositions pour résoudre des problèmes de conflit entre différentes conventions internationales ayant comme finalité trouver des solutions pour les droits et des obligations relatives à la biodiversité, aux ressources génétiques naturels, aux ressources économiques et sociales ainsi comme aux droits culturels.

* Professor, Universidad del Mar, Valparaíso. M. A. (Amsterdam), Ph. D. (c) (Ghent). Research Fellow, Institutional Dimensions of Global Environmental Change (University of California, Santa Barbara). Various papers related to the present article has been published in the Millennium Ecosystem Assessment. The author wants to thank scholarships, universities and institutes that has given the opportunity to develop part of the research. This is a draft from the final paper. 
SuMARIO: I. Conflicts of Legal Rules. II. International Law, International Politics and Intellectual Property Rights. III. A Solution. International Treaties and International Regimes.

IV. Conclusion.

\section{CONFLICTS OF LEGAL RULES}

At the international level treaties seems to conflict in matters of equitable sharing of benefits from Natural Genetic Resources. Various treaties rule the Natural Genetic Resources (NGRs) on areas like access to NGRs, sharing benefits from the utilization of NGRs, the intellectual property on NGRs and the rights to traditional knowledge associated to NGRs. The treaties that rule these topics are:

a) The Trade-Related Intellectual Property Rights (TRIPs) Agreement in the context of the World Trade Organization from 1994.

b) The Convention on Biological Diversity (CBD) from 1992.

c) The International Covenant on Economic, Social and Cultural Rights of 1969 (ICESCRs).

On one hand, TRIPs protect Intellectual Property Rights by means of recognition and enforcement of these rights at the national level, in particular by the inclusion and protection of genetic resources by patents and, on the other hand, the rights of countries and "people" have been protected by the CBD and the ICESCRs. Moreover, such international protection have to be applied in national law and to persons. Furthermore, such application have to consider the possible judgement of a conflict between norms in a jurisidiction, country or State different than the one in which such misconception has taken place.

Consequently, it might be possible to exclude protection for certain recognized rights because of "conflict of laws": Various legal rules (articles in various treaties) ruling at the same time the same facts, in this case, the utilization of genetic resources.

In certain cases the protection of one legal rule might exclude other legal rules from the possibility of protection of the resources.

In positive law, a harmonized interpretation is needed for the conflict between rights established by TRIPs, CBD and ICESRs.

\section{TRIPS}

TRIPs establish in Article 27 the scope of protection of patents and the exemptions to this protection: "1.Subject to the provisions of paragraphs 2 
and 3, patents shall be available for any inventions, whether products or processes, in all fields of technology, provided that they are new, involve an inventive step and are capable of industrial application".

And in number 3 of the same article exemptions have been included, as it is possible to read:

Members may also exclude from patentability:

(a) diagnostic, therapeutic and surgical methods for the treatment of humans or animals.

(b) plants and animals other than micro-organisms, and essentially biological processes for the production of plants or animals other than non-biological and microbiological processes. However, Members shall provide for the protection of plant varieties either by patents or by an effective sui generis system or by any combination thereof. The provisions of this subparagraph shall be reviewed four years after the date of entry into force of the WTO Agreement.

Patents are recognized by Article 27 of TRIPs for certain inventions that comply with requirements established by TRIPS. This recognition can override the recognition of other rights those that belong to the countries over their natural resources. ${ }^{1}$

Certainly life (plants, animals and essentially biological processes) has been excluded by an exemption. Than, what is included under the protection of TRIPs and, of course, under the protection of national law of countries that have ratified TRIPs?

a) Microorganisms. ${ }^{2}$

b) Essentially biological processes for the production of non-biological processes.

c) Essentially biological Processes for the production of microbiological processes.

A different situation is the case of plant varieties that shall be protected by a special system: patents, "sui generis system" or a combination.

1 This article will not discuss the problem of recognition and protection of rights of individuals that protect their rights at national level.

2 Technically speaking microorganisms are not animals. Biology has differentiated long ago on such different structures. 


\section{Article $8(J) C B D$}

The CBD, however, establishes in article 8 (j) the protection of the right to traditional knowledge and the right to sharing benefits arising from the commercialization of this traditional knowledge. ${ }^{3}$ The right to traditional knowledge might be considered a protection for Intellectual Property other than those protected by TRIPs and in agreement with ICESCRs. At the same time, in article 15 the CBD includes the recognition of sovereign rights o States over genetic resources, the basic elements of plants, animals and microorganisms. Article 8 states:

Each Contracting Party shall, as far as possible and as appropriate:

(j) Subject to its national legislation, respect, preserve and maintain knowledge, innovations and practices of indigenous and local communities embodying traditional lifestyles relevant for the conservation and sustainable use of biological diversity and promote their wider application with the approval and involvement of the holders of such knowledge, innovations and practices and encourage the equitable sharing of the benefits arising from the utilization of such knowledge, innovations and practices.

\section{Article $15 C B D$}

Article 15 of the CBD protects the interest of the society in an equitable sharing of benefits, as well as, of the public rights of the country. In accordance with Article 31.2 of the Vienna Convention of the Law on Treaties of 1967, a congruent interpretation is found in the context of treaties: in this case, sustainable development in Article 8 of TRIPs and Article 15 of the $\mathrm{CBD}$. Article 15 of the Convention sates the follwing:

Article 15. Access to genetic resources:

1. Recognizing the sovereign rights of States over their natural resources, the authority to determine access to genetic resources rests with the national governments and is subject to national legislation.

2. Each Contracting Party shall endeavour to create conditions to facilitate access to genetic resources for environmentally sound uses by other

3 Schoenbaum, T., "International Trade and Environmental Protection", en Birnie, P. y Boyle, A., International Law and the Environment, Oxford, Oxford University Press, 2002, p. 735. 
Contracting Parties and not to impose restrictions that run counter to the objectives of this Convention.

3. For the purpose of this Convention, the genetic resources being provided by a Contracting Party, as referred to in this Article and

Articles 16 and 19, are only those that are provided by Contracting Parties that are countries of origin of such resources or by the Parties that have acquired the genetic resources in accordance with this Convention.

4. Access, where granted, shall be on mutually agreed terms and subject to the provisions of this Article.

5. Access to genetic resources shall be subject to prior informed consent of the Contracting Party providing such resources, unless otherwise determined by that Party.

6. Each Contracting Party shall endeavour to develop and carry out scientific research based on genetic resources provided by other Contracting Parties with the full participation of, and where possible in, such Contracting Parties.

7. Each Contracting Party shall take legislative, administrative or policy measures, as appropriate, and in accordance with Articles 16 and 19 and, where necessary, through the financial mechanism established by Articles 20 and 21 with the aim of sharing in a fair and equitable way the results of research and development and the benefits arising from the commercial and other utilization of genetic resources with the Contracting Party providing such resources. Such sharing shall be upon mutually agreed terms.

\section{ICESCRS}

The ICESCRs establishes in Article 1 paragraph 2 the following: "All peoples may, for their own ends, freely dispose of their natural wealth and resources without prejudice to any obligations arising out of international economic co-operation, based upon the principle of mutual benefit, and international law. In no case may a people be deprived of its own means of subsistence".

\section{Hypothesis}

Four logical hypothesis of this interpretation exist:

A) Explicit protection of patents for genetic resources, foundations of life. In this case, plants and animals shall be inventions when they are new, they involve and inventive step and are capable of industrial application. It is the case of the letter $a$ ), b) and $c$ ) mentioned before. This protection is in accordance to Article 1 paragraph 2 of ICESCRs when the 
word people is refereed to persons or group of persons that are human beings.

B) Protection by the CBD taking into account the protection that the recognition of sovereignty and sovereign rights over these resources by article 15.

C) No protection by CBD or TRIPs.

D) Protection by CBD and TRIPs.

Some international initiatives have followed these interpretations by trying to include Intellectual Property Rights in TRIPs. This proposal has been unsuccessful. Nevertheless, in the CBD framework a project for an international regime on access and benefit sharing is being considered. In my opinion, a debate on how to share benefits is more fruitful, because this changes the problem from recognition of rights (expression of these rights in a legal rules) to application of rights (use of the recognized rights to solve cases). Consequently, a mechanism should be created to safeguard these rights.

In conclusion, the discussion on the problem between Intellectual Property Rights and other rights shows that this area is under development. Tension between implementation of Intellectual Property Rights $v s$. extension of other rights to protect communities and societies can find a solution. Since right-holders defend their benefits by exercising their rights, a mechanism for the implementation of intellectual property rights (individual or collective) and public rights is the best possible outcome. In this mechanism, when right-holders of Intellectual Property Rights and PRs contribute to research and development, these rights have a supremacy vis-à-vis Intellectual Property Rights. Sharing benefits will be on a case-by-case base, because every contribution to research needs to be rewarded.

It is necessary in order to understand the international situation to know origins and the debates on the tension between. Intellectual Property Rights and other rights. Therefore, the international process of Intellectual Property Rights related to Natural Genetic Resources will be studied.

\section{INTERNATIONAL LAW, INTERNATIONAL POLITICS AND INTELLECTUAL PROPERTY RIGHTS}

International regulations to Intellectual Property Rights have long history. First attempts dated back to 1961 when the International Union 
for the Protection of New Varieties of Plants (UPOV) was founded and the World Intellectual Property Organization (WIPO) followed it in 1967. ${ }^{4}$ The object of UPOV is the protection of new varieties of plants by an intellectual property right. WIPO, specialize agency of the United Nations administer intellectual property matters recognized by the Member States of this organization. The first international convention on this matter was enacted in 1885 and is called The Paris Convention on Intellectual Property. ${ }^{5}$

The question to be answered in this section is how conflicts between Intellectual Property Rights and other rights sculpt the actual debate on Intellectual Property Rights, because this debate is key to finding solutions to this problem. ${ }^{6}$ Traditionally, Intellectual Property Rights have been analysed in the context of private law. However, new international treaties change this form of analysis. Public law approach based on "public interest" in the framework of sustainable development makes this change possible.

The CBD is an international treaty that helps to understand the tension between Intellectual Property Rights and other rights. The CBD is a keystone in the long process of sustainable development since balance between environment, economic development and social welfare need to be obtained. ${ }^{7}$ To achieve this goal, the CBD calls for an equitable sharing of benefits (ESB) from the commercial use of Natural Genetic Resources (Articles 1 and $15 \mathrm{CBD}){ }^{8}$

In 1987 the United Nations Environmental Program (UNEP) Governing Council resolved to request an ad-hoc group of experts for the discussion of a new treaty on biodiversity and in 1989 and formal negotia-

4 WIPO, The Beginning, http://www.wipo.org/about-wipo/en/gib.htm\#P29_4637 (12.03.04); UPOV, Introduction, http://www.upov.int/ (12.03.04).

5 WIPO, Paris Convention on Industrial Property, http://www.wipo.int/clea/docs/ en/wo/wo020en.htm (18.01.04).

6 Schoenbaum, T., op. cit., nota 3, pp. 702-735.

7 Sanchez, V., "The Convention on Biological Diversity: Negotiation and Contents", en id. y Juma, C., Biodiplomacy: Genetic Resources and International Relations, ACTS Press, 1994, p. 9.

8 Secretariat of the Convention on Biological Diversity, Handbook of the Convention on Biological Diversity, Londres, Earthscan, 2001, pp. 4 y 11. 
tions started. ${ }^{9}$ Unfortunately, at this moment, a discussion about the implications of Intellectual Property Rights for Natural Genetic Resources and traditional knowledge was not on the agenda. Only the recognition and protection of Intellectual Property Rights as well as PRs have been possible. ${ }^{10}$

The protection of traditional intellectual property rights in the CBD is only related to technology. The CBD encourages protection of patents in developing countries, but only in the case of transference of technology. The Conference of the Parties (COP) of the CBD has been trying to address the problem of protection of individual and community intellectual property rights as well as public rights by various declarations and documents, some of them linking the protection of these rights directly with ESB. ${ }^{11}$ COP creates two Ad-Hoc Open Ended Working Groups, one on access and benefit sharing (Article 15, CBD) and the other on Traditional Knowledge (Article 8, j, CBD). At the same time, COP have tried to involve the WTO in solving the problem between individual intellectual and community intellectual property rights but, after no positive answer, the COP in decision V/26 have urged WTO to collaborate to solve the tension. ${ }^{12}$ In 2002, the 6th COP held in The Hague (the Netherlands) adopted the "Bonn Guidelines on access and benefit sharing", non-legally binding rules that were an attempt to solve the problem of ESB. ${ }^{13}$ Today an effort for the creation of an International Regime for Access and Benefit Sharing is a new initiative to solve this problem. ${ }^{14}$ The CBD has decided to solve the tension between Intellectual Property Rights and

9 Sanchez, V., op. cit., nota 7, pp. 8 y 9; Campeu, A., Canada's role in the negotiations of the Convention on Biological Diversity (12-00), www.bco.ec.gc.ca/en/who/default.cfm (23.11.03).

10 Svarstad, H., "National Sovereignty and Biological Resources", en Sanchez, V. y Juma, C., op. cit., nota 7, p. 45; North, S. Johnston, "South Tensions within the Convention on Biological Diversity", en Basse, E. M., Environmental Law (from International to National Law), Gad Jurio, Basse, 1997, p. 34.

11 Secretariat of the Convention on Biological Diversity, op. cit., nota 8, p. 11.

12 Ibidem, pp. 406, 409, 410, 489 y ss., 607, 608, 653, 654 y 656.

13 CBD, Decision VI/24 Access and Benefit-Sharing as Related to Genetic Resources: A. Bonn Guidelines on Access to Genetic Resources and Fair and Equitable Sharing of the Benefits Arising out of their Utilization (05.12.03), http://www.biodiv.org/ decisions/default.aspx? $\lg =0 \& m=$ cop $-06 \& d=24(07.12 .03)$.

14 Chambers, B., "WWSD and an International Regime on Access and Benefit Sharing: Is a Protocol the Appropriate Legal Instrument?", RECIEL 12 (3), 2003, p. 312. 
other rights, by creating working groups on the issue or by enacting of guidelines on the topic or by starting international negotiations on equitable sharing of benefits. ${ }^{15}$

The Trade Related Intellectual Property Rights (TRIPs) Agreement is one of the international agreements at the foundation of the tension between Intellectual Property Rights and private rights because it protects individual Intellectual Property Rights. At the same time, it is one of the pillars of the World Trade Organization. Since previous treaties related to IPR focus on certain sectors of intellectual property, TRIPs is the first treaty to face intellectual property in a holistic and primary manner and to establish fundamental standards of trade-related Intellectual Property Rights at the international and national levels. Members of the World Trade Organization shall implement at the national level, basic Intellectual Property Rights standards based on the legal obligations assumed by signing TRIPs. TRIPs protect Intellectual Property Rights related to trade because it is the main goal of this treaty. However, in other areas Intellectual Property Rights are not related with trade, like the case of folklore protected by some treaties from UNESCO. In other words, TRIPs help the whole trade building and without its existence, confidence in the trade world will never be established. ${ }^{16}$

Property Law differs from Intellectual Property Rights protected by TRIPs. Property Law, customarily, has ruled the area of Intellectual Property Rights. However, property law regulates mainly tangible assets. Intellectual Property Rights are related to intangible assets. ${ }^{17}$ Patents, one of the most important Intellectual Property Rights, protect individual Intellectual Property Rights (private rights on knowledge) and TRIPs in this context, is creating a market for patents. ${ }^{18}$

15 Exempli gratia, ad hoc Open-Ended Working Group on Access and Sharing of Benefits, Bonn Guidelines for Access and Equitable Sharing of Benefits, International negotiations for an International Regime for Access and Equitable Sharing of Benefits all of them described in the web page of the Secretariat of the Convention on Biological Diversity: http://www.biodiv.org.

16 Halle, M., "Foreword", en Dutfield, G., Intellectual Property Rights, Trade and Biodiversity, p. XII.

17 Abbot, F. et al., The International Intellectual Property System, Kluwer Law International, p. 23.

18 Abbot, F., "The enduring enigma of TRIPs: A challenge for the world system", Journal of International Economic Law, Oxford, Oxford University Press, 1998, p. 503. 
During the "Uruguay Round" of the General Agreement of Tariffs and Trade (GATT) debate arose out of intellectual property protection. As soon as a negotiation group on "trade related aspects of intellectual property rights" was established (March 1987), developing countries expressed that GATT's legal rules and future international legal norms on Intellectual Property Rights cannot be used in a protectionist manner. ${ }^{19}$ Moreover, these countries argued that historically GATT did not consider trade on Intellectual Property Rights as it has a focus on liberalization of trade on goods. Furthermore, jurisdictional problems were put forth, since WIPO was the organization in charge of these matters. Particularly, on patents, developing countries argued that it was not possible to accept "patentization" of plants, animals and micro-organisms, because these patents would affect the commercialization of these resources. Developed countries, on the contrary, argued for "patentization" of animals, plants and micro-organisms because their pharmaceutical industry could be affected in case of lack of protection. A final consensus was achieved in article 27 of TRIPs. The scope of patents' protection would be broad, but certain exemptions related to plants and animals were possible. This area remains under revision and possible modification. ${ }^{20}$

From 1994, onwards a large discussion about the protection of Intellectual Property Rights and PRs has been held. In recent years, patent offices around the world have granted patents protecting Intellectual Property Rights on Natural Genetic Resources without taking into account claims based on Intellectual Property Rights (e. g. Ayahuasca case).$^{21}$ In addition, groups of countries have put forth arguments to find a solution regarding to the clash between TRIPs and the CBD:

- Some countries have argued that CBD and TRIPs do not collide. Therefore, a review of article 27 could be only on the "patentability"

19 Ragavan, C. H., GATT vs. WIPO over Intellectual Property, South North Development Monitor, 20 de marzo de 1987.

20 World Trade Organization, Agreement on Trade Related Aspects on Intellectual Property Rights, Marrakesh, Morocco, 15 de abril de 2004, http://www.wto.org/english/tratop_eltrips_elt_agm2_e.htm (6.12.03).

21 Downes, D. y Weiser, G., "Intellectual property rights and national access and benefit sharing", en Laird, S., Biodiversity and Traditional Knowledge, Londres, Earthscan, 2002, p. 382. 
of biotechnological inventions and the protection of plant varieties, and not on Intellectual Property Rights and PRs. ${ }^{22}$

- Other countries propose exemption of Natural Genetic Resources and TK from patents and establishment of special regimes for Natural Genetic Resources and TK associated. ${ }^{23}$

- A third group of countries has pressed for change of TRIPs and inclusion of equitable sharing of benefits arising from patents over traditional knowledge. ${ }^{24}$ TRIPs need to include evidence of prior informed consent and disclosure of the source and country of origin in any patent application.

In Doha (Kuwait), the Ministerial Conference of the World Trade Organization (2002), decided to discuss a modification of TRIPs taking into account these different points of view. Unfortunately, negotiation for solution of the discussion failed in Cancun during 2003. ${ }^{25}$

In conclusion, TRIPs are the basic international standards and legal rules in matters related to Intellectual Property Rights. The whole building of intellectual property bases on these standards and they give much clarity and sense of stability to commerce (and environment), because it establishes basic requirements be protected by Intellectual Property Rights in any country.

It is possible to conclude that from 1986 onwards many changes occurred in the area of Natural Genetic Resources (and biological diversity) as well as Intellectual Property Rights. ${ }^{26}$ Discussion focus on all the topics related to IPR, definition, elements and other aspects. The tension

22 European Union, Review of Article 27.3 (B) of the TRIPs Agreement, and the relationship between the TRIPs agreement and the Convention on Biological Diversity CBD) and the protection of traditional Knowledge and Folklore, Submission to the Council for Trade Related Aspects of Intellectual Property Rights, IP/C/W/383, 17 de noviembre de 2003. Japan and the US included submission that for reasons of space will not be cited here.

23 Second LDC Trade Ministers' Meeting, Dhaka Declaration (Part 2), Dhaka Bangladesh, 02.06.03, LDC-II/2003/L/1/Rev 1, p. 1.

24 Bolivia et al., The Relationship Between the TRIP's Agreement and the Convention on Biological Diversity and the Protection of Traditional Knowledge, Submission to the WTO IP/C/W403 of 24.6.03, pp. 1 y 2.

25 Ministerial Conference of the WTO, Ministerial Declaration, WT/MIN(01)/ DEC/1, 20 de noviembre de 2001, p. 4.

26 This general conclusion may be found in Schoenbaum, J., op. cit., nota 3, p. 732. 
between Intellectual Property Rights and other rights is a framework to understand solutions chosen in the CBD and TRIPs on the issue of Natural Genetic Resources. However, the problem of sharing of benefits arising from Intellectual Property Rights on Natural Genetic Resources is not clear. Public interest is present in the text of TRIPs, and at the same time the CBD can support efforts of other international institutions to develop a mechanism of equitable sharing of benefits.

\section{A SOLUTION. INTERNATIONAL TREATIES AND INTERNATIONAL REGIMES}

TRIPs and CBD are related by "public interest" in the context of sustainable development; however, the tension between Intellectual Property Rights and other rights remain. ${ }^{27}$ This section addresses the relations between the treaties, because this is an important point for the possible solution of the tensions between Intellectual Property Rights and other rights. The explanation and arguments are applicable to the international as well as the national level. Before addressing the interrelationship between TRIPs and the CBD, it is necessary to look at the general regimes on trade and environment.

In a broad sense, interrelationships between trade and environment are not only related to Natural Genetic Resources. The World Trade Organization shields various treaties on areas like goods or service that collide with environmental treaties, because their rules do not consider the environmental dimension. ${ }^{28}$ Historically, trade has been a vehicle for development but its interest regarding environment is recent. Chemical products, oil and endangered biological diversity latu sensu are some of the "environmental" concerns of trade now a day. It is possible to distinguish three main areas of interest: protection against pollution, conservation of species and human relation and sustainable development. All of them, in different degrees, look at the conservation of environment:

a) By not polluting with chemicals or oil (Basel Convention On The Control of Trans-boundary Movements Of Hazardous Waste of 1999,

27 The word "regime" is used as synonym of international treaty or national rule depending on the context.

28 Roffe, P. et al., TRIPS and Development, Resource Book, UNCTAD/ICTSD, octubre de 2002, p. 12. 
The International Convention for the Prevention of Marine Pollution from Ships of 1978). ${ }^{29}$

b) By conserving species (Convention on International Trade in Endangered Species of Wild Fauna Flora of 1979).

c) By establishing the link between trade and environment trough sustainable development (Framework Convention on Climate Change or the $\mathrm{CBD}$ ).

Therefore, the relation between trade and environment in recent times has been of mutual support bearing in mind the concept of sustainable development. In the specific case of TRIPs and the CBD, the situation is different.

TRIPs and CBD protect "public interest", because both treaties look after the development of countries or people. In the case of TRIPs, "public interest" is achieved by preventing impediments and distortions of international trade; economic side of sustainable development and private interest plays an important role. In the case of CBD, "public interest" is achieved by rules that are related to Natural Genetic Resources in all dimensions: conservation and sustainable use of Natural Genetic Resources as well as sharing benefits arising from its commercialization. Environmental component of sustainable development and public interest play an important role here.

From another point of view, TRIPs look at the genetic information from a technological perspective. Genetic information could be considered no more than a natural resource that, after a process of transformation by technology, becomes a final product. The CBD, at the same time, focus on this genetic information obtained from plants, animals or micro-organisms belonging to certain state or information that a community possesses.

TRIPs and the CBD face difference too and these differences could be seen in a practical way, on the views related with Natural Genetic Resources or on a socio-legal view, on goals, perspectives, enforcement and protection of Intellectual Property Rights and mechanism to share benefits arising from Intellectual Property Rights.

29 Basel Convention on the Control of Trans-boundary Movements of Hazardous Waste of 1999 http://www.basel.int/text/con-e.htm (01.01.2003); The International Convention for the Prevention of Marine Pollution from Ships of $1978 \mathrm{http}: / / w w w . i m o . o r g /$ Conventions/mainframe.asp?topic_id=255 (01.01.03). 


\section{Goals}

Economic gain from Intellectual Property Rights is the first goal of TRIPs Agreement. Authors like J. Barton highlight this point. This author puts forth the benefits of TRIPs for pharmaceutical industry. Besides, he aggregates that TRIPs creates a minimum international standard for Intellectual Property Rights protection. ${ }^{30}$ Moreover, P. Roffe, explains that the Preamble of TRIPs Agreement is a source of interpretation of the treaty. In the preamble is stated the main objective of TRIPs. Moreover, article 1 makes this view explicit. ${ }^{31}$ The preamble expresses that TRIPs has a mission: "to reduce distortions and impediments to international trade, and taking into account the need to promote effective and adequate protection of intellectual property rights". ${ }^{32}$

Article 1 of TRIPs obliged members of the treaty to implement Intellectual Property Rights based on the standards settled in TRIPs.

Conservation, sustainable use and fair and equitable sharing of benefits arising out of the utilization of Natural Genetic Resources utilization of biodiversity and Natural Genetic Resources are the goals of the CBD. ${ }^{33}$ As expressed by J. Mugabe and others, these three goals of the Convention on Biological Diversity are equally important. ${ }^{34}$

However, he argues that the most important one is the third one, because it provides a direct incentive for conservation and sustainable use and supplies "development benefits as well". Today equitable sharing of benefits is considered one of the possible solutions for tension between Intellectual Property Rights. ${ }^{35}$ Above all, the objectives of the convention, according to J. Mugabe, repair inequities related to transactions on Intellectual Property Rights, because benefits obtained from the commercialization of their Natural Genetic Resources was not received in developing countries. ${ }^{36}$

30 Barton, J., TRIPs as it relates to $S \& T$, Stanford Law School, 2 de septiembre de 2003, p. 2.

31 Roffe, P. et al., op. cit., nota 28, p. 114.

32 World Trade Organization, op. cit., nota 20.

33 Secretariat of the Convention on Biological Diversity, op. cit., nota 8, p. 11.

34 Mugabe, J. et al., Access to Genetic Resource, Bonn, IUCN, 1997, p. 7.

35 Sanchez, V., op. cit., nota 7, pp. 8 y 9.

36 Mugabe, J. et al., Access to Genetic Resource, nota 34, p. 7. 


\section{Perspectives}

Intellectual Property Rights are related to benefits that arise from trade. T. Cottier explains that Intellectual Property Rights are rules to maintain fair competition and in this form, gains from trade will arise. ${ }^{37}$ This is called a traditional perspective on TRIPs and is related to the process of negotiations of this treaty. As expressed before, this view is included in the Preamble and articles of this international agreement. However, a new perspective is emerging. P. Roffe argues that negotiators of TRIP consider public interest as well as the pure economic perspective. It is recognized in the Preamble: "[T] he underlying public policy objectives of national systems for the protection of intellectual property, including developmental and technological objectives". ${ }^{38}$

Moreover, in Article 7, TRIPs include explicitly the contribution of Intellectual Property Rights "to social and economic welfare and to a balance of rights and obligations". Furthermore, the development dimension can be recognized in article 8 of TRIPs where it is stated that members may take measures: "[T] promote the public interest in sectors of vital importance to their socio-economic and technological development". ${ }^{39}$

Therefore, the perspective of sustainable development and public interest are included in TRIPs as a way of interpreting the treaty at the international but particularly at the national level. Taking into account these arguments Barton proposes a reform of TRIPs as well as IP. Two reasons are at the foundations of this new perspective: need of science and the common knowledge (or traditional knowledge) and developing countries' interests on access to medicine or technology. ${ }^{40}$

The CBD, on the other hand, is an international regime on environment and sustainable development. Authors like V. Sanchez and others have put this perspective forth. ${ }^{41}$ Sustainable development plays a key role in the conservation, sustainable use and commercialization of Natu-

37 Cottier, T., "Intellectual Property in International Trade Law and Policy: The Gatt Connection", en Abbot, F. et al., The International..., cit., nota 17, p. 12.

38 World Trade Organization, op. cit., nota 20.

39 Idem.

40 Barton, J., Reforming TRIPS and IP, Stanford Law School, 6 de septiembre de 2003, p. 2.

41 Sanchez, V., op. cit., nota 7, p. 8. 
ral Genetic Resources. In commercialization, intellectual rights play a fundamental role, as those rights are conceived to generate gains from trade that can help sustainable development. Since Intellectual Property Rights will play an important role in the implementation of the CBD since these rights protect technology to be used by the industry, M. Illesca, one specialist in the area of intellectual property declares that the CBD protects Intellectual Property Rights. ${ }^{42}$ However, Posey considers that the situation of indigenous peoples' Intellectual Property Rights was not well handled in the CBD. He points out that the recognition of their rights is not enough because a mechanism for enforcement of these rights in not in place. ${ }^{43}$

Both international treaties have different goals and perspectives in the "short term" but in the "long term" the development dimension has an important place, because "public interest" is a possible argument for the solution of the tension between Intellectual Property Rights and other rights. ${ }^{44}$

Patents are relevant for the implementation of the CBD as they play a key role in defining who gains access to information about Natural Genetic Resources. Access to Natural Genetic Resources will be possible only when private contracts and national laws recognize Intellectual Property Rights and PRs.

Authors have discussed the relation between CBD and TRIPs trying to solve debate between public and private law. Some of them adhere to TRIPs or CBD or they support another possible solution that integrates both treaties. This discussion is not strictly related to the topic of biopiracy but it affects it. The positions are:

\section{Exclusive support to TRIPS}

L. Boland supports TRIPs by putting forth that the equitable theory of TRIPs propose high levels of Intellectual Property Rights protection, strengthening developing countries economies. In addition, new Intellectual Property Rights infrastructures would encourage local innovation as

42 Illescas, M., "Intellectual Property Institutions and Technological Co-Operation", en Sanchez, V. y Juma, C., op. cit., nota 7, p. 202.

43 Posey, D., "International Agreements for Protecting Indigenous Knowledge", en Sanchez, V. y Juma, C., op. cit., nota 7, pp. 120 y 121.

44 Abbot, F., Intellectual Property Rights, Trade and Biodiversity, p. 498. 
developing country inventors are enabled to exploit the fruits of their own labor. TRIPs will encourage foreign enterprises to transfer technology, because of legal protection under national law. Foreign direct investment would increase since the local situation is friendlier to technology protection. ${ }^{45}$ Other arguments were raised in favor of TRIPs, for example, that the supply of knowledge in developing countries would increase because of the disclosure of the patents' information. In short, protection of traditional Intellectual Property Rights is the best alternative for developing countries in order to achieve sustainable development.

\section{Exclusive support to the $C B D$}

V. Anuradha points out that the CBD changes the point of discussion from Natural Genetic Resources as free and accessible good for all to Natural Genetic Resources under the protection of the State. The CBD is a political and legal attempt to face the problem of free access to Natural Genetic Resources. At the same time, the CBD is a mechanism that can address the interests of local communities and indigenous people, who have knowledge about biological diversity. ${ }^{46}$ Anuradha concentrate on the importance of CBD for the process of protection of Natural Genetic Resources and Intellectual Property Rights related to them.

\section{Integrating certain common elements from TRIPs and CBD}

A third group represented by W. Fisher and F. Abbot, look for solutions to differing views on Intellectual Property Rights. They try to find common positions by proposing that each country could negotiate individual contracts with industries that are interested in gaining access to genetic material or traditional knowledge. This solution is based on the existence of national legal rules that "prevents the companies from gaining access to local materials or knowledge without consenting to such a

45 Boland, L., "Current and Future Policy Changes", OECD Conference on IPR, Innovation and Economic Performance, París, 28 y 29 de agosto de 2003, p. 6, http://www.oecd.org/dataoecd/49/33/12763998.pdf (10.01.03)

46 Anuradha, R., "Intellectual Property Rights: Implications for Biodiversity and Lo cal and Indigenous Communities”, RECIEL 10 (1), 2001, p. 29. 
deal" ${ }^{47}$ At the same time, Abbot proposes an interpretation of TRIPs taking the public dimension established in Article 8 into account. ${ }^{48}$ According to these authors, a solution is possible by re-interpreting TRIPs and/or establishing new legal rules at the national level.

\section{CONCLUSION}

In conclusion, the concept of IPR and other aspects are under discussion, because they are not easy to understand and define among experts. At first sight TRIPS and CBD could differ in goals, perspectives, right protected as well as in matters of enforcement. However, it is clear that both regimes have something in common; a commitment towards sustainable development and public interest. Moreover, apart from differing opinions on advantages of one or another international treaty it is possible to derive certain solutions. In the national implementation process of both international agreements, countries try to solve the conflicts and solutions.

47 Fisher, W., "Managing Genetic Resources", en Fisher, W. y Field, M., Legal Reform in Central America: Dispute Resolution and Property Systems, Massachusetts, Kennedy School of Government, 2001, p. 5.

48 Abbot, F., Intellectual Property Rights, Trade and Biodiversity, p. 498. 